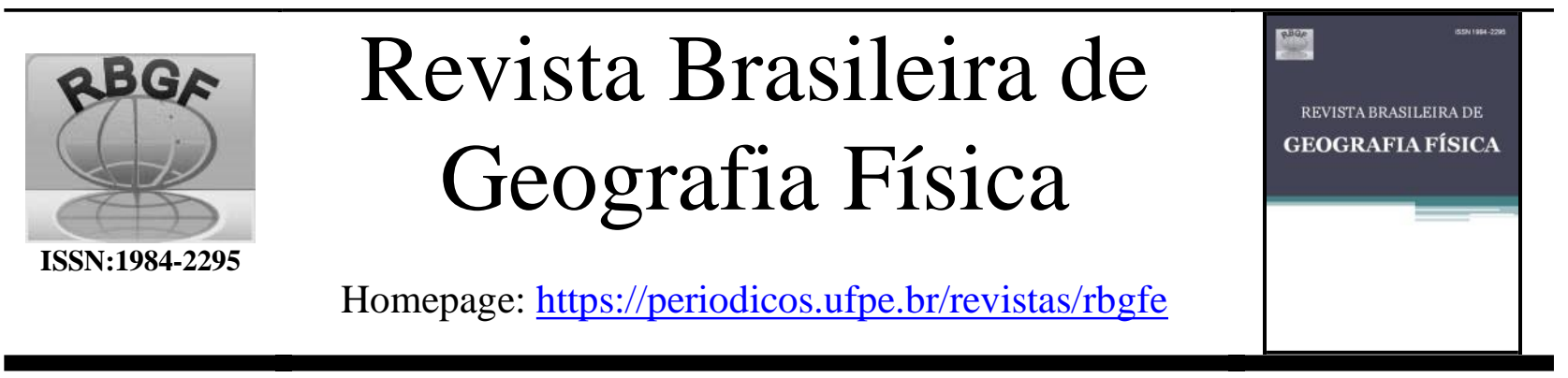

\title{
Comparison of the Reference Evapotranspiration among Empirical Methods and Penman-Monteith in Semiarid Region of Northeastern Brazil
}

Jhon Lennon Bezerra da Silva. Federal Rural University of Pernambuco (UFRPE), Dom Manoel de Medeiros

Avenue, Recife, Pernambuco, Brazil, ZIP code 52171-900. E-mail: jhonlennoigt@ hotmail.com (Autor correspondente);

Alan Cézar Bezerra. Federal Rural University of Pernambuco (UFRPE), Serra Talhada Academic Unit (UAST); Ceres Duarte Guedes Cabral de Almeida. Prof ${ }^{a}$ Ceres Duarte Guedes Cabral de AlmeidaColégio Agrícola Dom Agostinho Ikas - CODAI. Programa de Pós-graduação em Engenharia Agrícola - PGEA. Universidade Federal Rural de Pernambuco - UFRPE

Dayane Farias Lima. Federal Rural University of Pernambuco (UFRPE), Dom Manoel de Medeiros Avenue, Recife, Pernambuco, Brazil, ZIP code 52171-900.

Fernanda Helena Nascimento de Andrade. Federal Rural University of Pernambuco (UFRPE), Dom Manoel de Medeiros Avenue, Recife, Pernambuco, Brazil, ZIP code 52171-900.

Keila Jerónimo Jiménez. Federal Rural University of Pernambuco (UFRPE), Dom Manoel de Medeiros Avenue, Recife, Pernambuco, Brazil, ZIP code 52171-900.

\section{A B S T R A C T}

Artigo recebido em 09/11/2014 e a ceito em 24/02/2015

The reference evapotranspiration (ETo) is a complex measure essential to water resources planning and management, irrigation scheduling, and rational agricultural water use. This research aimed to evaluate the performance of the empirical methods in estimating reference evapotranspiration based on daily meteorological data of the surface and comparing them with the standard method of Penman-Monteith (PM-FAO 56), during the period of January/2004 to December/2013 for the climatic conditions of the semiarid region of Brazil. Five empirical methods were evaluated: Hargreaves-Samani (HS), Camargo (C), Thornthwaite (Th), Priestley-Taylor (PT), and Jensen-Haise (JH). For this purpose, maximum air temperature $\left(\mathrm{T}_{\max },{ }^{\circ} \mathrm{C}\right)$ and minimum $\left(\mathrm{T}_{\min },{ }^{\circ} \mathrm{C}\right)$; maximum air relative humidity $\left(\mathrm{RH}_{\max }, \%\right)$ and minimum $\left(\mathrm{RH}_{\min }, \%\right)$; maximum air atmospheric pressure $\left(\mathrm{P}_{\max }, \mathrm{kPa}\right)$ and minimum $\left(\mathrm{P}_{\min }, \mathrm{kPa}\right)$; average wind speed at a height of 2 meters $\left(\mathrm{u}_{2} \mathrm{~m}, \mathrm{~m} \mathrm{~s}^{-1}\right)$; global solar radiation $\left(\mathrm{MJ} \mathrm{m}^{-2}\right)$; and precipitation $(\mathrm{mm})$ were used at this study. Analysis data were executed using descriptive statistics, correlation, dispersion, and statistical accuracy indexes to compare empirical models with the PM-FAO 56. The JH method overestimated the standard Penman-Monteith method, and underestimated by the HS, C, Th, and PT methods, on a monthly average scale. In general, HS and JH methods had better adjustments with PM-FAO 56, on a daily scale. In conclusion, empirical methods, on a daily scale, presented good correlations and satisfactory statistical indices, being important in agricultural planning and irrigation management, becoming a good alternative for semiarid conditions of Petrolina-PE in San Francisco mesoregion.

Keywords: San Francisco Valley, irrigation management, drought, meteorological data, water resources.

\section{Comparação da Evapotranspiração de Referência entre Métodos Empíricos e Penman-Monteith em Região Semiárida do Nordeste Brasileiro}

\section{R E S U M O}

A evapotranspiração de referência (ETo) é uma medida complexa essencialao planejamento e manejo dos recursos hídricos, manejo de irrigação e uso ra cional da á gua na a gricultura. Oobjetivo deste tra balho foi a valiar a precisão de métodos empíricos na estimativa da evapotranspiração de referência baseados em dados meteorológicos diários de superfície, comparando-os com o método padrão de Penman-Monteith da FAO-56 (PM-FAO 56), durante o período de janeiro/2004 a dezembro/2013,

Silva, J. L. B., Bezerra, A. C., Almeida, C.D.C., Lima, D. F., Andrade, F. H. N., Jiménez, K.J. 
Revista Brasileira de Geografia Física v.14, n.01 (2021) 001-015.

para as condições climáticas da região semiárida do Brasil. Foram ava liados cinco métodos empíricos: Hargreaves-Samani (HS), Camargo (C), Thornthwaite (Th), Priestley-Taylor (PT) e Jensen-Haise (JH). Para tanto, foram utilizados as seguintes variáveis: temperatura máxima do $\operatorname{ar}\left(\mathrm{T}_{\max },{ }^{\circ} \mathrm{C}\right)$ e mínima $\left(\mathrm{T}_{\min },{ }^{\circ} \mathrm{C}\right)$; umidade relativa máxima do ar $\left(\mathrm{RH}_{\max }, \%\right)$ e mínima $\left(\mathrm{RH}_{\min }, \%\right)$; pressão atmosférica máxima do $\operatorname{ar}\left(\mathrm{P}_{\max }, \mathrm{kPa}\right)$ e mínima $\left(\mathrm{P}_{\min }, \mathrm{kPa}\right)$; velocidade média do vento a uma altura de 2 metros $\left(\mathrm{u}_{2 \mathrm{~m}}, \mathrm{~m} \mathrm{~s}^{-1}\right)$; radiação solar global $\left(\mathrm{MJ} \mathrm{m}^{-2}\right)$; e precipitação $(\mathrm{mm})$. A análise dos dados foi realizada por meio da esta tística descritiva, correlação, dispersão e índices estatísticos para comparar os modelos empíricos com o PM-FAO 56. O método de JH superestimou o método padrão de Penman-Monteith, enquanto que ocorreu a subestimativa pelos métodos de HS, C, Th e PT, na escala média mensal. Em geral, os métodos de HS e JH tiveram melhores ajustes com o PM-FAO 56, na escala diária. Em conclusão, os métodos empíricos, na escala diária, apresentaram boas correlações e índices estatísticos satisfatórios, sendo importantes no planejamento agrícola e manejo da irrigação, tornando-se uma boa alternativa para condições semiáridas de Petrolina-PE na Mesorregião do São Francisco.

Pala vras-chave: Vale do São Francisco, manejo da irrigação, seca, dados meteorológicos, recursos hídricos.

\section{Introduction}

Water scarcity is a notable and increasingly present problem, especially in the semiarid regions of the world, with long periods of drought due to the irregularity of rain. In the Brazilian semiarid region, which is characterized by low rainfall and few water reserves, the estimation of reference evapotranspiration (ETo) is high, thus justifying climatology and meteorology studies (Barbosa et al., 2018; Oliveira et al., 2020).

Evapotranspiration is the simultaneous process of water transfer to the atmosphere both by soil water evaporation and plant transpiration. The study of this parameter is essential for adequate irrigation management, water resources planning and management, and rational agricultural water use (Salama et al., 2015; Pandey et al., 2016; Yang et al., 2019). The determination of evapotranspiration is as well important for the studies of hydrology, climatology, and meteorology (Djaman et al., 2018).

Since agriculture represents $70 \%$ of Brazil's water consumption, the correct ETo estimation supports the farmer's decision about the quantity the irrigation depth should be supplied to the soil during crop cycle and irrigation frequency (Oliveira et al., 2020). Consequently, the plant does not suffer from a deficit or excess of water, which in turn causes a reduction in productivity and environmental impacts, such as leaching of nutrients and soil salinization (Althoff et al., 2018).

Weather and crop parameters are factors affecting evapotranspiration, since it is dependent on the crop characteristics, size of the covered crop area, and soil water content (Koksal et al., 2017). As a result, evapotranspiration is essential in activities related to river basin management. However, among the different components of the hydrological cycle, a precise approximation of evapotranspiration is perhaps most difficult due to its complex interactions with the soil-plant-atmosphere system (Pandey et al., 2016).
The complexity of direct measurement has been overcome by technological advances in electronic data collection systems (Mariano et al., 2015). There are different ways of estimating ETo, for example, indirect methods that make the adjustments of meteorological data with mathematical models, making them faster and more feasible for this type of study (Liu et al., 2016).

The Food and Agriculture Organization (FAO) recommend the Penman-Monteith model (FAO56- PM) as the standard method to estimate evapotranspiration due to present better results for ETo estimation with climate variables and the interactivity characteristic between the physical base and the physiological and aerodynamic parameters of the plants (Allen et al., 1998; Shiri, 2017). As a result, agronomists, irrigation engineers, and other scientists have commonly used this model. The PenmanMonteith model was also used to calibrate other empirical and semi-empirical ETo models.

On the other hand, this method depends on several meteorological data (e.g. air temperature, relative humidity, solar radiation, and wind speed), frequently unavailable, which makes difficult the large-scale usage, especially to smaller farmers. Another point is, all the weather data needed to attend the FAO56- PM are often incomplete in many of the developing countries like Senegal (Djaman et al., 2015) and Brazil, mainly the semiarid area (Fernandes et al., 2018).

From the technological advances in the electronic systems of data collection, it is possible to estimate the reference evapotranspiration efficiently by empirical methods. However, the use of empirical or semi-empirical ETo equations with fewer meteorological parameters is only recommended under certain situations where complete weather data are lacking. Since also different empirical equations overcome these disadvantages with high precision and accuracy, using few meteorological elements

Silva, J. L. B., Bezerra, A. C., Almeida, C.D.C., Lima, D. F., Andrade, F. H. N., Jiménez, K.J. 
Revista Brasileira de Geografia Física v.14, n.01 (2021) 001-015.

(Lacerda and Turco, 2015; Pandey et al., 2016; Althoff et al., 2018; Oliveira et al., 2020).

The success of a model to estimate ETo in a particular area often depends on the climate of the region. Therefore, the selection of an appropriate model based on the availability of data and the performance of the ETo estimation model is a hard decision (Muhammad et al., 2019). In an attempt to evaluate different empirical methods, some studies have been carried out in semiarid regions (Shiri, 2017; Valipour et al., 2017; Djaman et al., 2018), inclusive in the northeast region of Brazil (Oliveira et al., 2020).

There is an effort to select the ETo estimation method suitable for a given site, by scientific studies comparing ETo estimation methods with the FAO56PM method verifying the accuracy of methods, seeking the ETo estimation method that best represents the local conditions. Thus, the San Francisco Valley, which is of great importance for irrigated agricultural production semiarid areas in the northeast of Brazil, is a priority area for scientific studies in this sense. The municipality of Petrolina, located at the center of San Francisco Valley, has been highlighted by the irrigated agricultural area and respective yield, which makes it a model for the state of Pernambuco (Guimarães Junior, 2016; Marengo et al., 2016; Barbosa et al., 2018).

Therefore, efficient and sustainable use of water, especially in the irrigated districts like Nilo Coelho Public Project in San Francisco Valley, implies in the correct dimensioning of the irrigation projects, aiming to guarantee the sustainable management of the agricultural systems and promote adaptation in the management of agriculture in front to the future condition of water availability in these regions (Salama et al., 2015; Li et al., 2016). Due to the severe water deficit conditions in the Brazilian semiarid, this study shows full interest in evaluating and monitoring the water resources through estimating losses by evapotranspiration, essential for the adequate management of irrigation.

Due to the lack of studies in semiarid regions in the northeast of Brazil, this research hypothesis that according to the data scale and local adjustments may increase accuracy in the estimation of the reference evapotranspiration by an empirical method focused on the climatic conditions of San Francisco Valley.

To contribute to the knowledge of this nature, this study evaluated the accuracy of five methods of estimation on reference evapotranspiration: Hargreaves-Samani (HS),
Camargo (C), Thornthwaite (Th), Priestley-Taylor $(\mathrm{PT})$, and Jensen-Haise (JH) comparing to the standard physical method of Penman-Monteith (FAO56- PM), for the San Francisco Mesoregion, municipality of Petrolina-PE, in the semiarid region of northeastern Brazil. Thus, a database daily scale of the following variables was used: air temperature; air relative humidity, air atmospheric pressure; wind speed at a height of 2 meters; global solar radiation and precipitation, during 10 years from 2004 to 2013.

\section{Material and methods}

\section{Characterization of the study area}

The state of Pernambuco has favorable edaphoclimatic conditions for the fruit growing, and irrigation allows producing a great variety of tropical fruits with expressive results in the last years. However, one of the barriers to maintaining productivity is the prolonged dry season, as a result, irrigation technology assumes an indispensable role, but water resource use should be optimized due to the current global water scarcity.

The San Francisco Mesoregion has a characteristic climate of the Brazilian Semiarid where the municipality of Petrolina is inserted. This region was selected for this study because represents high agricultural potential. San Francisco Mesoregion is geographically located between the parallels of $08^{\circ} 37^{\prime} 30^{\prime \prime} \mathrm{S}$ and $09^{\circ} 29^{\prime} 10^{\prime \prime} \mathrm{S}$ and between the meridians of $40^{\circ} 1^{\prime} 30^{\prime \prime} \mathrm{W}$ and $40^{\circ} 56^{\prime}$ $30^{\prime \prime} \mathrm{W}$, and altitude of $365.5 \mathrm{~m}$, zone $24 \mathrm{~S}$, west of the Green wich meridian (Figure 1). According to the classification of Köppen, the type climate is BSw'h' with a dry climate and low summer rains and the average annual temperature is $26.3{ }^{\circ} \mathrm{C}$. Two welldefined seasons, where 80 to $90 \%$ of the annual rainfall predominates during the rainy season (summer) that is between January and April, with mean annual total rainfall of $567 \mathrm{~mm}$ (Alvares et al., 2013). The dry season in this region is extensive and it is present from autumn until spring, when the water scarcity strongly affects the region, whereas agricultural production is only possible through intensive use of irrigation.

Surface meteorological data

The surface meteorological database was obtained from an automatic meteorological station which belongs to the National Institute of Meteorology (INMET), located in the study area at geographic coordinates: $9^{\circ} 23^{\prime} 17.96^{\prime \prime} \mathrm{S}$ and $40^{\circ} 31^{\prime}$

Silva, J. L. B., Bezerra, A. C., Almeida, C.D.C., Lima, D. F., Andrade, F. H. N., Jiménez, K.J. 
23.74" W, and $373 \mathrm{~m}$ altitude. Data collection was performed hourly or daily, according to the intrinsic climate variable characteristics. The data records started on February 21, 2003. Thus, maximum air temperature $\left(\mathrm{T}_{\max },{ }^{\circ} \mathrm{C}\right)$ and minimum $\left(\mathrm{T}_{\min },{ }^{\circ} \mathrm{C}\right)$; maximum air relative humidity $\left(\mathrm{RH}_{\max }, \%\right)$ and minimum $\left(\mathrm{RH}_{\min }, \%\right)$; maximum air atmospheric pressure $\left(\mathrm{P}_{\max }, \mathrm{kPa}\right)$ and minimum $\left(\mathrm{P}_{\min }, \mathrm{kPa}\right)$; wind speed at a height of 2 meters $\left(\mathrm{u}_{2 \mathrm{~m}}, \mathrm{~m} \mathrm{~s}^{-1}\right)$; global solar radiation $\left(\mathrm{MJ} \mathrm{m}^{-2}\right)$; and precipitation $(\mathrm{mm})$ were used at this study, during 10 years from January 2004 to December 2013.
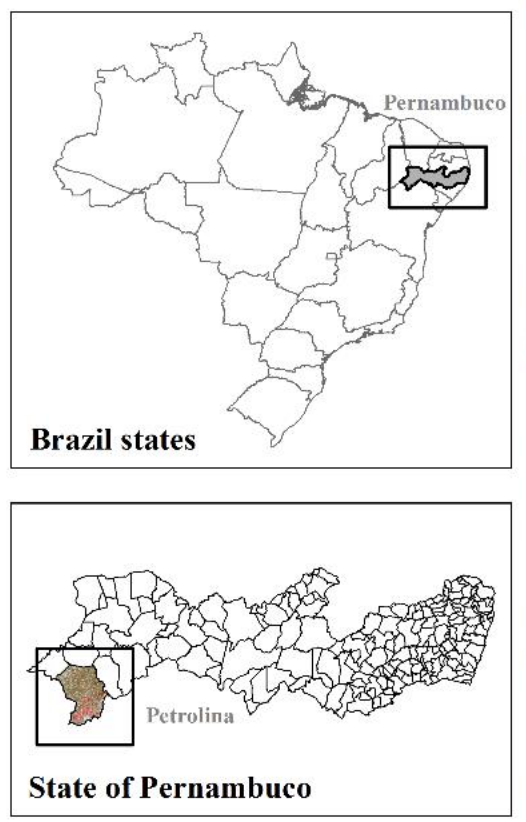

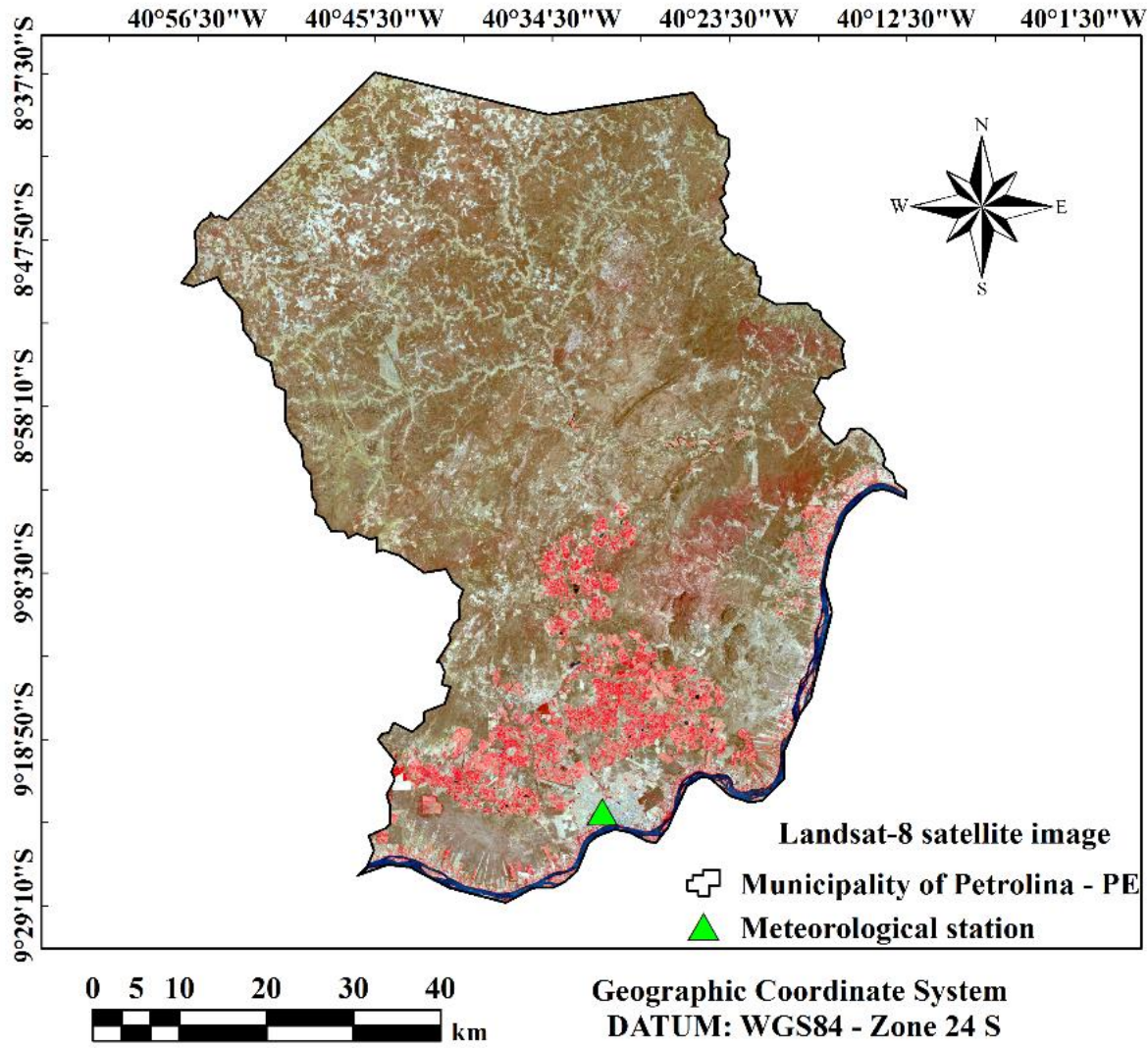

Figure 1. Spatial map of the location of the study area, Petrolina, Pernambuco, Brazil. Landsat-8 satellite image infra-red.

The precision of scientific research requires a complete database of meteorological parameters collected at regular intervals. The occurrence of missing measurements in the database reduces the accuracy of the findings of the research. Unfortunately, it is particularly common to obtain a meteorological database with missing data, due to a lack of measurement in conventional stations for technical problems (Bier and Ferraz, 2017). To overcome this problem, there are different methods in the literature by filling these gaps. In this study, the multiple linear regression method was used from the database of other neighboring stations over the same period.

The database of the period selected was organized daily using an electronic spreadsheet. For each meteorological variable, reference evapotranspiration values were calculated. Therefore, the observed meteorological data were provided as an input into the standard PenmanMonteith physical method (Allen et al., 1998) and by empirical methods: Hargreaves-Samani (1985), Thornthwaite (1948), Camargo (1971), PriestleyTaylor (1972) and Jensen-Haise (1963).

Reference evapotranspiration estimation equations

The five equations that estimate the reference evapotranspiration, evaluated in this study, were selected based on their simplicity in terms of the number of climatic parameters needed to solve them. In addition to Penman-Monteith physical method (FAO56- PM) adopted as a standard. 
Standard method of Penman-Monteith(FAO56-PM)

The ETo $\left(\mathrm{mm} \mathrm{day}{ }^{-1}\right)$ was determined by standard Penman-Monteith physical model FAO 56 as applied by Equation 1 (Allen et al., 1998).

$$
\mathrm{ET}_{\mathrm{o}}=\frac{0.408 \times \Delta\left(\mathrm{R}_{\mathrm{n}}-\mathrm{G}\right)+\gamma \frac{900}{\left(\mathrm{~T}_{\text {med }}+273\right)} \times \mathrm{u}_{2}\left(\mathrm{e}_{\mathrm{s}}-\mathrm{e}_{\mathrm{a}}\right)}{\Delta+\gamma \times\left(1+0.34 \times \mathrm{u}_{2}\right)}
$$

Where, 0.408 corresponds to $1 / \lambda$, where $\lambda$ is the latent heat evaporation of water equal to $2.45 \mathrm{MJ} \mathrm{kg}$ 1 at $20{ }^{\circ} \mathrm{C}$; The constant 900 , corresponds to a conversion factor referring to the daily data scale; $R_{n}$ is the net radiation $\left(\mathrm{MJ} \mathrm{m}^{-2} \mathrm{day}^{-1}\right) ; \mathrm{G}$ is the heat flux in the soil $\left(\mathrm{MJ} \mathrm{m}^{-2} \mathrm{day}^{-1}\right) ; \gamma$ is the psychrometric constant $\left(0.064 \mathrm{kPa}^{\circ} \mathrm{C}^{-1}\right)$, calculated according to the atmospheric air pressure; $\mathrm{T}_{\text {med }}$ is the average daily temperature $\left({ }^{\circ} \mathrm{C}\right)$ found from maximum and minimum air temperatures measured at the station; $\mathrm{u}_{2}$ is the wind velocity at $2 \mathrm{~m}$ height $\left(\mathrm{m} \mathrm{s}^{-1}\right)$; $\mathrm{e}_{\mathrm{s}}$ is the saturation pressure of the daily mean water vapor $(\mathrm{kPa})$, obtained by data from the automatic meteorological station, according to Equation 2; $\mathrm{e}_{\mathrm{a}}$ is the actual mean daily vapor pressure of water $(\mathrm{kPa})$, calculated according to the $\mathrm{e}_{\mathrm{s}}$ and also through meteorological data, according to Equation $3 ; \Delta$ is the slope of the vapor pressure curve at saturation $(\mathrm{kPa}$ $\left.{ }^{\circ} \mathrm{C}^{-1}\right)$, obtained according to Equation 4 and $\left(\mathrm{e}_{\mathrm{s}}-\mathrm{e}_{\mathrm{a}}\right)$ is the vapor saturation deficit.

$$
\mathrm{e}_{\mathrm{s}}=0.6108 \times \exp \left(\frac{17.27 \times \mathrm{T}_{\text {air }}}{237.3+\mathrm{T}_{\text {air }}}\right)
$$

Where $\mathrm{T}_{\text {air }}\left({ }^{\circ} \mathrm{C}\right)$ is the instantaneous air temperature.

$$
\mathrm{e}_{\mathrm{a}}=\frac{\mathrm{RH} \times \mathrm{e}_{\mathrm{s}}}{100}
$$

Where $\mathrm{RH}(\%)$ is air relative humidity.

$$
\Delta=\frac{4098 \times \mathrm{e}_{\mathrm{s}}}{\left(\mathrm{T}_{\mathrm{air}}+273.3\right)^{2}}
$$

\section{Hargreaves-Samani (1985)}

Hargreaves-Samani (1985) proposed a method to estimate the reference evapotranspiration, expressed as Equation 5. FAO recommends this method, according to Allen et al. (1998) when only air temperature data are available because it is an empirical radiation-based method, which is extensively used in the conditions of limited weather data.

$$
\text { ETo }_{(\mathrm{HS})}=0.0023 \times \mathrm{R}_{\mathrm{a}}(\mathrm{T}+17.8) \sqrt{\mathrm{T}_{\max }-\mathrm{T}_{\min }}
$$

Where, ETo ${ }_{(\mathrm{HS})}$ is the reference evapotranspiration $\left(\mathrm{mm} \mathrm{day}{ }^{-1}\right) ; \mathrm{R}_{\mathrm{a}}$ is extraterrestrial solar radiation incident at the top of the atmosphere $\left(\mathrm{mm} \mathrm{day}^{-1}\right)$, to obtain in mm day-1, the values are divided by 2.45 ; $\mathrm{T}$ is the average daily temperature, $\mathrm{T}_{\max }$ maximum temperature and $\mathrm{T}_{\min }$ minimum temperature $\left({ }^{\circ} \mathrm{C}\right)$.

Thornthwaite's Method (1948)

Two equations were proposed for the determination of ETo with Equation 6 satisfying the condition of $0{ }^{\circ} \mathrm{C} \leq \mathrm{T}_{\mathrm{i}} \leq 26{ }^{\circ} \mathrm{C}$ and Equation 7 the condition of $\mathrm{T}_{\mathrm{i}}>26^{\circ} \mathrm{C}$ (Thornthwaite, 1948).

$$
\begin{aligned}
& \operatorname{ETo}_{(\mathrm{Th})}=16\left(10 \frac{\mathrm{T}_{\mathrm{i}}}{\mathrm{I}}\right)^{\mathrm{a}} \\
& \operatorname{ETo}_{(\mathrm{Th})}=-415.85+32.24 \mathrm{~T}_{\mathrm{i}}-0.43 \mathrm{~T}_{\mathrm{i}}^{2}
\end{aligned}
$$

Where, $\mathrm{ETo}_{(\mathrm{Th})}$ is the reference evapotranspiration $\left(\mathrm{mm}\right.$ month $\left.^{-1}\right) ; \mathrm{T}_{\mathrm{i}}\left({ }^{\circ} \mathrm{C}\right)$ is the monthly average air temperature; I and a are the thermal indices imposed by the local climate regime, these are calculated according to Equations 8 and 9 , where $\mathrm{T} \geq 0{ }^{\circ} \mathrm{C}$ has to be adopted.

$$
\mathrm{I}=\sum_{\mathrm{n}=1}^{12}\left(0.2 \mathrm{~T}_{\mathrm{i}}\right)^{1.514}
$$

$$
\begin{aligned}
& \mathrm{a}=6.75 \times 10^{-7} \mathrm{I}^{3}-7.71 \times 10^{-5} \mathrm{I}^{2}+1.7912 \times 10^{-2} \mathrm{I} \\
& +0.49239
\end{aligned}
$$

Where, I correspond to the sum of the 12 monthly $i$ indexes ( $i=1$, January; ...; $i=12$, December).

Equations 6 and 7 provide evapotranspiration for the standard condition of months with 30 days and days with 12 hours of sunshine. To obtain the daily evapotranspiration, the value obtained by the equations is multiplied by the following correction factor (C), according to Equation 10 (Pereira et al., 1997).

$$
\mathrm{C}=\frac{\mathrm{N}}{12} \times \frac{1}{30}
$$

\footnotetext{
Silva, J. L. B., Bezerra, A. C., Almeida, C.D.C., Lima, D. F., Andrade, F. H. N., Jiménez, K.J.
} 
Where $\mathrm{N}$ is the photoperiod (h) of a given day.

The photoperiod is calculated according to the latitude of the site and the solar declination, through Equation 11 (Varejão-Silva, 2006).

$\mathrm{N}=\frac{2}{15} \times \mathrm{i}_{(\mathrm{s})}$

Where, $N$ is the photoperiod (h) and $i_{(s)}$ is the hour angle relative to sunrise or sunset, obtained by Equation 12.

$\mathrm{i}_{(\mathrm{s})}=\arccos (-\tan \phi \times \tan \delta)$

Where $\phi$ latitude of the site; $\delta$ the solar declination.

Camargo’s Method (1971)

Camargo (1971) proposed a method to determine the reference evapotranspiration, as observed in Equation 13.

ETo $_{(\mathrm{CA})}=\mathrm{R}_{\mathrm{a}} \times \mathrm{T} \times \mathrm{K}_{\mathrm{f}} \times \mathrm{ND}$

Where, $\mathrm{ETo}_{(\mathrm{CA})}$ is the reference evapotranspiration $\left(\mathrm{mm}\right.$ day $\left.^{-1}\right) ; \mathrm{R}_{\mathrm{a}}$ is the extraterrestrial solar radiation incident above the atmosphere on the 15th day of each month (MJ m ${ }^{-2}$ day $^{-1}$ ) and to obtain $\mathrm{R}_{\mathrm{a}}$ in $\mathrm{mm}$ day $^{-1}$, the values are divided by 2.45 ; ND is the number of days in the analyzed period; $\mathrm{T}$ is the annual mean air temperature of the site $\left({ }^{\circ} \mathrm{C}\right)$ and $\mathrm{K}_{\mathrm{f}}$ is the adjustment factor that varies with the annual mean air temperature of the site $\left(\mathrm{K}_{\mathrm{f}}=0.01\right.$ for $\mathrm{T}<23$ ${ }^{\circ} \mathrm{C}, \mathrm{K}_{\mathrm{f}}=0.0105$ for $\mathrm{T}=24{ }^{\circ} \mathrm{C}, \mathrm{K}_{\mathrm{f}}=0.011$ for $\mathrm{T}=25$ ${ }^{\circ} \mathrm{C}, \mathrm{K}_{\mathrm{f}}=0.0115$ for $\mathrm{T}=26{ }^{\circ} \mathrm{C}$ and $\mathrm{K}_{\mathrm{f}}=0.012$ for $\mathrm{T}>$ $\left.26{ }^{\circ} \mathrm{C}\right)$

Priestley-Taylor's Method(1972)

This next physical method calculates the evaporating power of air according to Equation 14 (Priestley and Taylor, 1972).

$\mathrm{ETo}_{(\mathrm{PT})}=\frac{1.26 \times \mathrm{W}\left(\mathrm{R}_{\mathrm{n}}-\mathrm{G}\right)}{\lambda}$

Where, ETo ${ }_{(\mathrm{PT})}$ is the reference evapotranspiration $\left(m m\right.$ day $\left.^{-1}\right) ; R_{n}$ is the radiation balance; $\mathrm{G}$ is the heat flux in the soil; $\mathrm{W}$ is the weighting factor obtained according to Equation $15 ; \lambda$ is the latent heat of vaporization $\left(2.45 \mathrm{MJ} \mathrm{kg}^{-1}\right)$.

$$
\mathrm{W}=\frac{\Delta}{\Delta+\gamma}
$$

Where, $\Delta$ is the slope of the vapor pressure curve obtained by the constant psychrometric equation $(\gamma)$.

Jensen-Haise's Method(1963)

According to studies developed in semiarid regions of North America, Jensen and Haise (1963) proposed the relation for reference evapotranspiration - ETo $\left(\mathrm{mm}\right.$ day $\left.^{-1}\right)$, according to Equation 16 (Pereira et al., 1997).

$$
\text { ETo }_{(\mathrm{JH})}=\mathrm{R}_{\mathrm{s}}(0.0252 \times \mathrm{T}+0.078)
$$

Where $\mathrm{T}$ is the mean air temperature $\left({ }^{\circ} \mathrm{C}\right)$ and $\mathrm{R}_{\mathrm{s}}$ is the global solar radiation at the surface $\left(\mathrm{cal} \mathrm{cm}^{-2}\right.$ day $\left.{ }^{1}\right)$.

Statistical analysis

The data were submitted to descriptive statistical analysis using the determination of the central tendency (mean and median) measures and dispersion measures such as standard deviation (SD), variance, and coefficient of variation (CV). According to the criteria by Warrick and Nielsen (1980), the classification of CV (\%) split into the following: $\quad \mathrm{CV}<12 \% \quad$ (low variability), $12 \%<\mathrm{CV}<60 \%$ (mean variability), and $\mathrm{CV}>60 \%$ (high variability).

The evaluation of the ETo estimate methods was performed by linear regression analysis to verify the existence of a functional relationship between the methods, considering the estimate of the ETo by the PM-FAO 56 method as the independent variable, and the reference evapotranspiration estimation by the other methods as a dependent variable.

The accuracy of the estimates was evaluated by the coefficient of determination $\left(\mathrm{R}^{2}\right)$. The agreement index (d) of Willmott et al. (1985) expresses the accuracy of the estimates with the observed values, ranging from zero indicating nullity to one indicating perfect agreement, which is determined by Equation 17.

$$
\mathrm{d}=1-\frac{\sum\left(\mathrm{P}_{\mathrm{i}}-\mathrm{O}_{\mathrm{i}}\right)^{2}}{\sum\left(\left|\mathrm{P}_{\mathrm{i}}-\mathrm{O}\right|+\left|\mathrm{O}_{\mathrm{i}}-\mathrm{O}\right|\right)^{2}}
$$

Where Oi is the estimated value of ETo by the PMFAO 56 method; $\mathrm{Pi}$ is the ETo value estimated by the empirical methods; $\mathrm{O}$ is the mean of the estimated 
ETo values by the PM-FAO 56 method and $i$ is the number of events.

The performance evaluation of the adjustment of each method was realized based on the performance index proposed by Camargo and Sentelhas (1997), denoted as "c", which results from the product of the precision index " $r$ " (Pearson correlation coefficient), expressed by Equation 18, and agreement index "d" by Willmott et al. (1985), expressed according to Equation 19.

$$
\mathrm{r}=\frac{\sum_{\mathrm{i}=1}^{\mathrm{N}}\left(\mathrm{O}_{\mathrm{i}}-\mathrm{O}\right) \times\left(\mathrm{P}_{\mathrm{i}}-\mathrm{P}\right)}{\sqrt{\sum_{\mathrm{i}=1}^{\mathrm{n}}\left(\mathrm{O}_{\mathrm{i}}-\mathrm{O}\right)} \times \sqrt{\sum_{\mathrm{i}=1}^{\mathrm{n}}\left(\mathrm{P}_{\mathrm{i}}-\mathrm{P}\right)}}
$$

Where, $\mathrm{O}_{\mathrm{i}}$ is the estimated value of ETo by the PMFAO 56 method; $\mathrm{P}_{\mathrm{i}}$ is the ETo value estimated by the empirical methods; $\mathrm{O}$ is the mean of the estimated ETo values by the PM-FAO 56method; $P$ is the mean value estimated by empirical methods and $i$ is the number of events. For interpretation of the performance of the adjustment of each method, the criteria in Table 1 were used.

$$
\mathrm{c}=\mathrm{r} \times \mathrm{d}
$$

Table 1. Criteria for interpretation of the performance of the adjustment of each method based on the coefficient (c) of Camargo and Sentelhas (1997).

\begin{tabular}{cc}
\hline c & Performance \\
\hline$>0.85$ & Excellent \\
$0.76-0.85$ & Very good \\
$0.66-0.75$ & Good \\
$0.61-0.65$ & Regular \\
\hline
\end{tabular}

In addition to the above-mentioned indexes, the root mean square error (RMSE), the mean absolute error (MAE), and the mean relative error (MRE) were calculated between the estimated evapotranspiration by empirical methods and the PM-FAO 56 as the standard method.

The RMSE (Equation 20) characterizes the variance of the errors in the estimate, considering that the lower the RMSE value, the better the method adjustment.

$$
\text { RMSE }=\sqrt{\frac{\sum_{\mathrm{i}=1}^{\mathrm{n}}\left(\mathrm{P}_{\mathrm{i}}-\mathrm{O}_{\mathrm{i}}\right)^{2}}{\mathrm{~N}}}
$$

Equations 21 and 22 refer to the absolute and relative mean errors which help in the understanding of errors generated by each of the empirical methods used, thus, the higher these indices the worse the estimation of the variable under analysis, ETo.

$$
\begin{aligned}
& \text { MAE }=\frac{\sum_{\mathrm{i}=1}^{\mathrm{n}}\left|\mathrm{P}_{\mathrm{i}}-\mathrm{O}_{\mathrm{i}}\right|}{\mathrm{N}} \\
& \mathrm{MRE}=\frac{100}{\mathrm{~N}} \sum_{\mathrm{i}=1}^{\mathrm{n}}\left|\frac{\mathrm{P}_{\mathrm{i}}-\mathrm{O}_{\mathrm{i}}}{\mathrm{O}_{\mathrm{i}}}\right|
\end{aligned}
$$

Where $\mathrm{N}$ is the number of observations.

Thus, errors provided by the estimates were also verified using the standard estimation error (SEE). This index also indicates the quality of the adjusted model and how much the error of the estimate of a dependent variable occurs on average. Thus, Figueredo Dantas et al. (2016) state that the lower the SEE, the better adjusted the model (Equation 23).

$$
\mathrm{SEE}=\sqrt{\left[\frac{\sum\left(\mathrm{P}_{\mathrm{i}}-\mathrm{O}\right)^{2}}{\mathrm{~N}-2}\right]}
$$

Then, the best performance of each model was detected concerning the evaluation of statistical indices.

\section{Results and discussion}

The empirical methods allow obtaining ETo in a simplified and fast way using the minimum of meteorological parameters for the semiarid conditions of the municipality of Petrolina-PE, in San Francisco Valley, during the rainy and dry periods.

The descriptive statistics analysis that denotes the minimum, maximum, mean, median, standard deviation, and coefficient of variation are shown in Table 2. The ETo estimated were classified as medium variation, as observed in the $\mathrm{CV}$ values (17 to $27 \%$ ), according to the criteria by Warrick and Nielsen (1980). The daily ETo values ranged from 4.44 to $7.32 \mathrm{~mm} \mathrm{day}^{-1}$ with Th and $\mathrm{JH}$ methods presenting the lowest and highest values respectively. 
Compared among the empirical methods studied, JH presented a higher standard deviation $(\mathrm{SD}=1.95)$ next to the PT method $(\mathrm{SD}=1.26)$ and followed by the $\mathrm{C}$ method $(\mathrm{SD}=1.09)$, consequently, they also presented greater variability in ETo estimates than when compared mainly with the Penman-Monteith method ( $\mathrm{CV}=20 \%)$, as shown by the $\mathrm{CV}$ values $(27,24$ and $22 \%$, respectively). In contrast, the Th $(\mathrm{CV}=17 \%)$ and $\mathrm{HS}(\mathrm{CV}=19 \%)$ methods showed less variability throughout the study period (Table 2).

Table 2. Descriptive statistics analysis of daily reference evapotranspiration (ETo) estimated by PM-FAO 56 standard method and empirical methods evaluated between January 2004 and December 2013, Petrolina - PE.

\begin{tabular}{ccccccc}
\hline \multirow{2}{*}{ Method } & \multicolumn{7}{c}{ Descriptive statistics } \\
\cline { 2 - 7 } & Minimum & Maximum & Mean & Median & SD & CV (\%) \\
\hline PM-FAO 56 & 3.38 & 8.53 & 6.17 & 6.29 & 1.24 & 20 \\
Jensen-Haise & 3.10 & 10.90 & 7.32 & 7.70 & 1.95 & 27 \\
Priestley-Taylor & 2.57 & 7.37 & 5.15 & 5.45 & 1.26 & 24 \\
Camargo & 2.74 & 6.56 & 4.90 & 5.06 & 1.09 & 22 \\
Thornthwaite & 2.84 & 5.84 & 4.44 & 4.64 & 0.76 & 17 \\
HS & 2.84 & 6.69 & 4.90 & 5.04 & 0.92 & 19 \\
\hline
\end{tabular}

PM-FAO 56- standard physical method of Penman-Monteith FAO 56; HS - Hargreaves and Samani; SD - standard deviation; CV coefficient of variation.

The evapotranspiration values estimated by the JH method were overestimated compared to the standard FAO56-PM(Figure 2), between 5 and 24\%, for both the rainy and dry seasons in the region. The historical analysis indicates that there is possibly replacing the standard method just between June to
September, when the overestimate degree remained below $10 \%$, on a monthly average daily scale of 10 consecutive years.

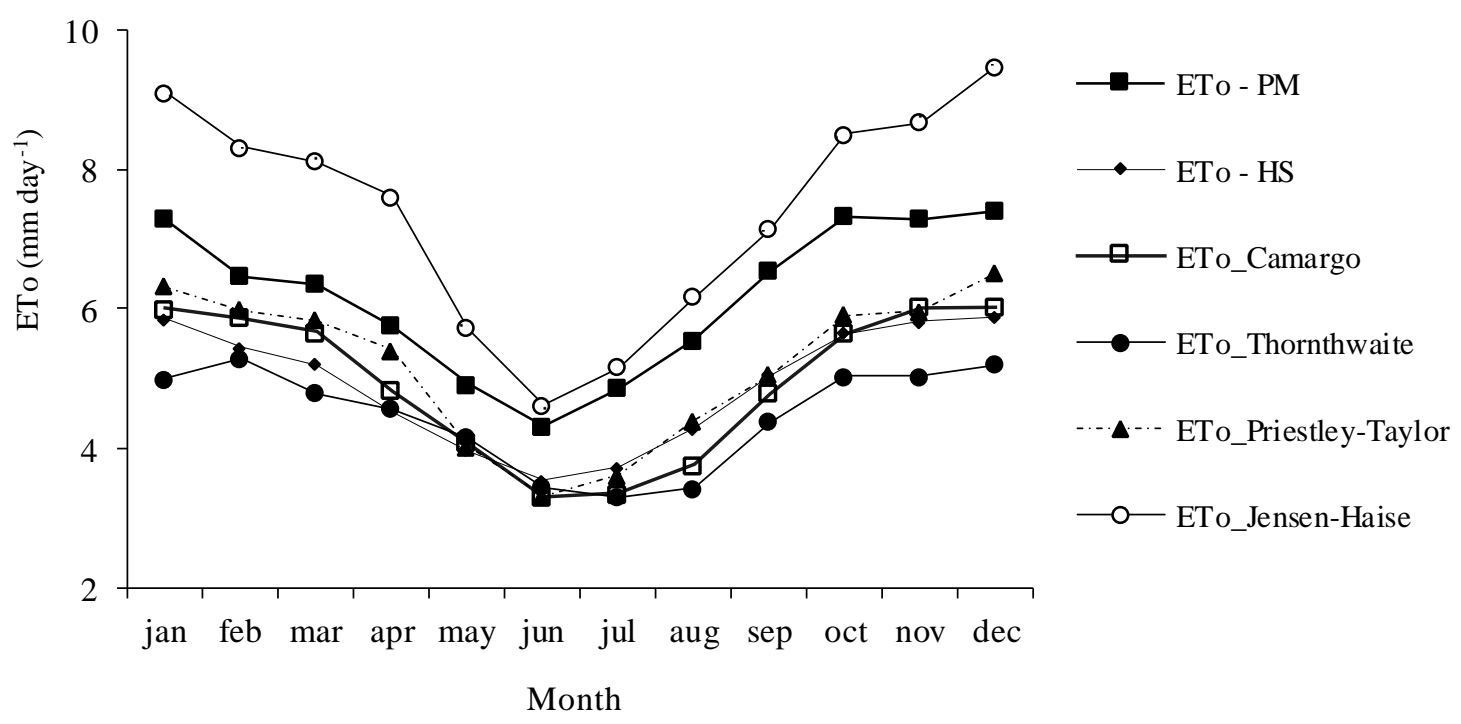

Figure 2. Monthly averages of reference evapotranspiration (ETo, $\mathrm{mm} \mathrm{day}^{-1}$ ) obtained by PM-FAO 56 standard method and empirical methods, between January 2004 and December 2013, Petrolina - PE. 
In the same way, on the monthly average scale, the empirical HS, C, Th, and PT methods underestimated the evapotranspiration values estimated by the PM-FAO 56 equation, between the percentages of 9 and $55 \%$. With greater discrepancy found by Th method, which showed underestimation ranging between 27 and 55\% (Figure 2). However, the results presented on the monthly average daily scale show the need for better local adjustments to obtain precision and accuracy in the determination of ETo by the different empirical methods for the Petrolina-PE region.

Figueredo Dantas et al. (2016) also evaluated the performance of empirical methods in the semiarid region in the state of Paraiba, with similar responses, that is, they overestimated the PM-FAO 56 equation; the authors emphasized best adjustments in the models to reduce the overestimation to have precision in the ETo determination.

On the other hand, the graphical analysis performed by the regression graphs of the empirical methods against the standard reference method (PMFAO 56) for the long-term period (10 years) with

A

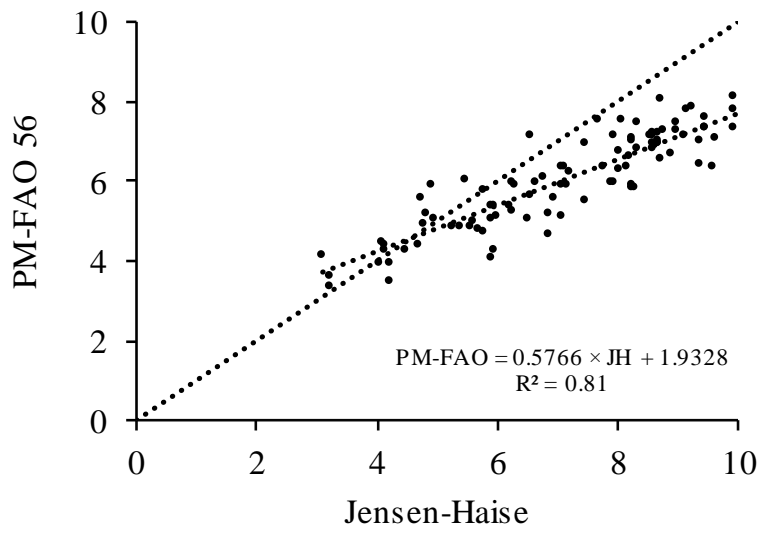

C

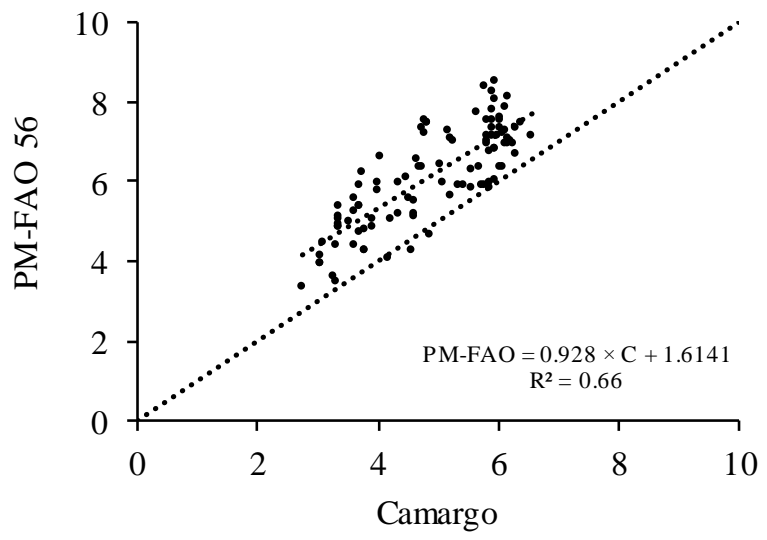

consecutive data exhibited in Figure 3. Thus, for a daily scale, the graphical analysis shows that there is a relationship between reference evapotranspiration by PM-FAO 56 and empirical methods. In particular, the HS and $\mathrm{JH}$ methods presented the highest determination coefficients " $\mathrm{R}^{2}=0.83$ " (Figure $3 \mathrm{E}$ ) and 0.81 (Figure 3A), respectively.

Visual analysis of the graphs in Figure 3 is confirmed to the evaluation criteria of the empirical methods analyzed showed in Table 3 . The coefficient of correlation " $\mathrm{r}=0.91$ and 0.90 " and confidence indices " $c=0.83$ and 0.82 ", respectively to the HS and $\mathrm{JH}$ methods, corroborate the graphical analysis. Thus, these empirical methods could replace the standard method PM- FAO 56 to estimate ETo, the daily scale, while data are absent.

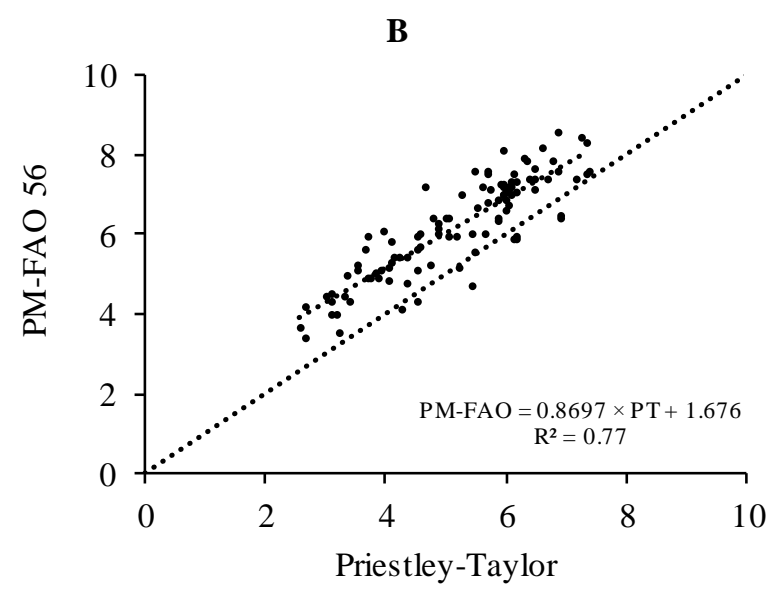

D

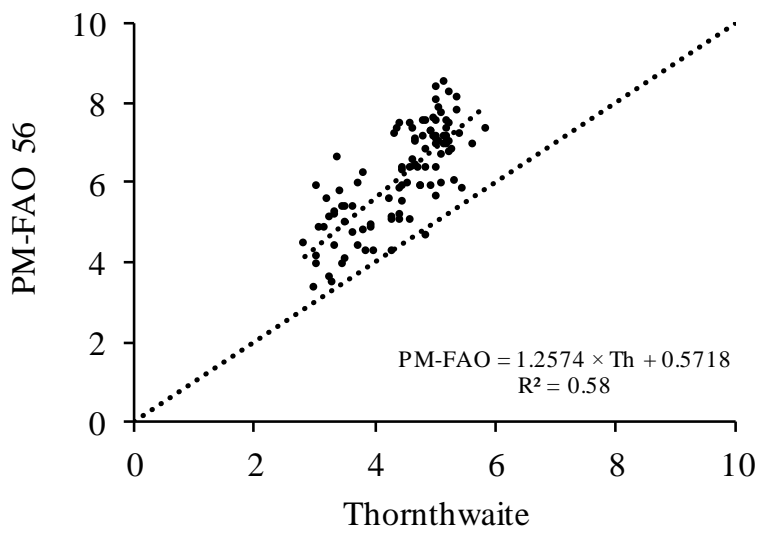

$\mathbf{E}$ 


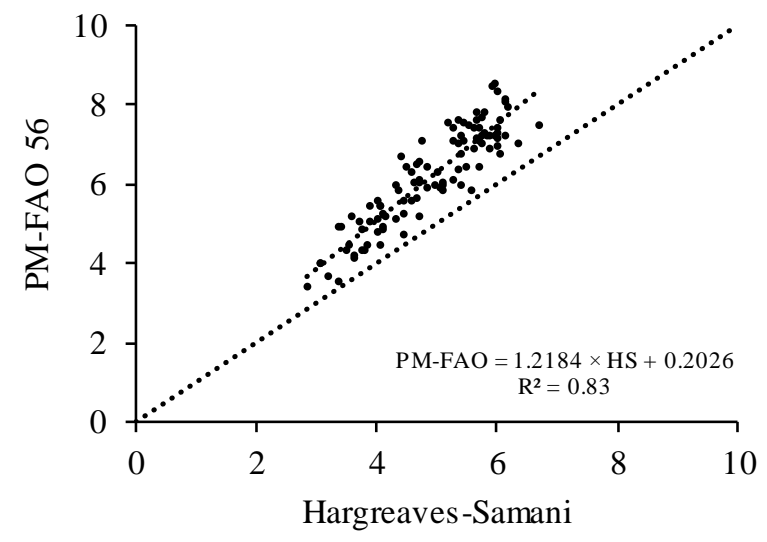

Figure 3. The relation between reference evapotranspiration by PM-FAO 56 and empirical method between January 2004 and December 2013, Petrolina - PE.

Studies conducted in the state of Pernambuco highlighted satisfactory results of the determination of ETo by the HS method that corroborate the present research, with a "very good" performance (Arraes et al., 2016; Ide and Silva, 2017). However, for the daily scale, analyzing the 10 consecutive years of data (Table 2), empirical methods are highlighted. Thus, according to the performance classification proposed by Camargo and Sentelhas (1997), these methods presented ETo estimated ranging from "very good" (HS, JH, PT, and C methods) to "good" (Th method). As a result, indicating good correlation coefficients $(r=0.76$ to 0.91 , Table 3), when compared with the standard equation (PM-FAO 56) for the Petrolina-PE, San Francisco Valley region.

Lucena et al. (2016) evaluated the weather conditions in the municipality of Bom Jesus, the state of Piauí, also a semiarid region in the Northeast of Brazil. They assessed different methods of estimation of the ETo (Hargreaves-Samani, Ivanov, Camargo, Priestley-Taylor, and Jensen-Haise). However, contrary to our findings, they pointed out that the Hargreaves-Samani method had a poor performance in the rainy season $(c=0.575)$. On the other hand, Lucena et al. (2016) concluded that the worst performers were found to methods of Ivanov and Camargo, as well, in this study Camargo and Thornthwaite were also the worst options to estimate ETo to the municipality of Petrolinain São Francisco Valley. Hence, these findings correspond to the higher data dispersion and are represented by the coefficient of determination (Figure 3), 0.66 and 0.58 , respectively. These results are according to Althoff etal. (2018) that modeling and comparing the
ETo from different heuristic methodologies confirmed that Thornthwaite's method resulted in a lower determination coefficient, $\mathrm{R}^{2}=0.39$.

Some findings by Sales et al. (2018) and Oliveira et al. (2020) also obtained similar responses to this study with "good" performance in the ETo estimates, on a daily scale, using the empirical method JH. According to Santos et al. (2017), these responses were expected because the $\mathrm{JH}$ method was developed for arid and semiarid regions, explaining the appropriate application for the San Francisco Valley region, represented here by the Petrolina-PE.

The Priestley-Taylor method was also highlighted in the present work because, in addition to presenting a "very good" performance in the estimation of ETo, on the daily scale, it had the smallest errors among the other empirical methods (Table 3 ). The good correlation between PriestleyTaylor and PM-FAO $56\left(\mathrm{R}^{2}=0.77 ; \mathrm{d}=0.94 ; \mathrm{r}=\right.$ $0.88 ; \mathrm{c}=0.83$; Table 3 ) also indicates the replacement for ETo estimation.

In contrast to the Th method that presented the largest errors, although it also stood out against the statistical indexes and with "good" performance (Table 3). Some studies highlighted that the Th and HS methods did not have favorable application in semiarid regions, as observed by Carvalho et al. (2015), unlike the present study that presented satisfactory results on a daily scale. Thus, depending on the time scale used on the historical series, adjustments can be modified and improved, as also observed by Sales et al. (2018), the "bad" performance that studies on a daily scale and "good" on a monthly scale.

Silva, J. L. B., Bezerra, A. C., Almeida, C.D.C., Lima, D. F., Andrade, F. H. N., Jiménez, K.J. 
Revista Brasileira de Geografia Física v.14, n.01 (2021) 001-015.

Table 3. Statistical analysis of correlation on different empirical methods evaluated between January 2004 and December 2013, Petrolina - PE.

\begin{tabular}{|c|c|c|c|c|c|c|c|c|c|}
\hline \multirow{2}{*}{ Method } & \multirow[b]{2}{*}{$\mathbf{R}^{2}$} & \multicolumn{3}{|c|}{ Indexes } & \multirow[b]{2}{*}{ Performance $^{1}$} & \multicolumn{4}{|c|}{ Error } \\
\hline & & d & $\mathbf{r}$ & c & & SEE & MRE & RMSE & MAE \\
\hline Jensen-Haise & 0.81 & 0.92 & 0.90 & 0.82 & very good & 1.63 & 20.52 & 1.61 & 1.20 \\
\hline Priestley-Taylor & 0.77 & 0.94 & 0.88 & 0.83 & very good & 1.24 & 17.57 & 1.23 & 0.97 \\
\hline Camargo & 0.66 & 0.96 & 0.81 & 0.78 & very good & 1.48 & 20.32 & 1.47 & 1.16 \\
\hline Thornthwaite & 0.58 & 0.87 & 0.76 & 0.66 & good & 2.00 & 28.17 & 1.98 & 1.60 \\
\hline HS & 0.83 & 0.91 & 0.91 & 0.83 & very good & 1.51 & 20.12 & 1.50 & 1.20 \\
\hline
\end{tabular}

$\mathrm{R}^{2}$ - Determination index; $\mathrm{d}$ - Willmott Index; $\mathrm{r}$ - Correlation coefficient; $\mathrm{c}$ - Confidence index; SEE - standard error of estimation; MRE mean relative error; RMSE - root mean square error; MAE - mean absolute error. ${ }^{1}$ Camargo and Sentelhas (1997)

Ide and Silva (2017) compared the adjustment of the empirical equations for the estimation of the reference evapotranspiration in comparison with the FAO 56 standard method in the area of influence of the transposition of the São Francisco River, presenting "bad" performance for Th method, on a monthly scale. It is worth mentioning the conditions of local climate change from one region to another, when the semiarid regions, as is the case of this study, have a prominent place due to water scarcity and long periods of drought. Lucena et al. (2016) comparing ETo estimation methods mentioned Priestley-Taylor and Penman-Monteith-FAO-56 as being less sensitive to changes in atmospheric variables. They also pointed out that for properly accurate estimatesit is necessary to parameterize them according to local conditions.

The methods that used global solar radiation meteorological data obtained better confidence indices compared to the methods that only use the air temperature. Sales et al. (2018) and Lucena et al. (2016) observed a similar response, evaluating the adjustments of empirical evapotranspiration methods over the standard method. The good adjustment on the methods is due to the similarity with the PM-FAO 56 method where it used practically the same meteorological variables. However, the applications of these methods can be restricted when some of these variables are not available and/or do not register in some research sites, mainly about solar radiation (Djaman et al., 2015).

Oliveira et al. (2020) studied the comparison of empirical methods correlated with the standard Penman-Monteith FAO 56 method in a hydrographic basin in the state of Rio Grande do Norte. Thus, the authors noted that the Radiation and Linacre methods performed "very good" throughout the rainy season and recommended them for ETo estimates for use in irrigation projects because of their good correlation with the standard method.

The application of efficient practices and technologies, the example of empirical methods, is essential for planning and development mainly in the agricultural sector, rationally and sustainably, such which the irrigation is what more consumes water. The economy in the use of irrigation water especially in semiarid regions is necessary for the water shortage in the Northeast of Brazil (Andrade Junior et al., 2015).

In this way, the application of empirical methods studied can meet the need to determine reference evapotranspiration when meteorological variables are absent that prevent the determination by the PM-FAO 56 method, in monthly and daily data scale. They can be used especially when there is only solar radiation and air temperature data in different climatic periods.

Brazilian public policies of water resources must support these alternatives as suggestions to decrease the water demand and expand the irrigated area in Brazil (Fernandes et al., 2018) based on the perspective of water rational use. The crops' water requirement is higher in the drier seasons when are not supplied by rainfalls, then the only solution is full irrigation. However, evapotranspiration estimation can contribute to reducing efficient irrigation management. Therefore, the farmers should select an effective evapotranspiration estimation method as suggested by this study, for example, the HargreavesSamani method which has exhibited good performance on evapotranspiration estimation to the study area. Fernandes et al. (2018) also recommend

Silva, J. L. B., Bezerra, A. C., Almeida, C.D.C., Lima, D. F., Andrade, F. H. N., Jiménez, K.J. 
this method to the Cerrado region of Brazil, due to its present good performance, besides that has a low cost in terms of parameters required, such as temperature and solar radiation, which become accessible to most farmers in Brazil.

As highlighted in the present study, the semiarid region of northeastern Brazil is characterized as the region most vulnerable to droughts. Besides that, water scarcity and little knowledge about trends in water loss through evaporation and transpiration (evapotranspiration) request further researches (Cabral Júnior et al., 2019). Thus, the ETo is a determining factor in understanding droughts in the semiarid region. Drought events linked to climate change promote variations in meteorological parameters, mainly affecting ETo and consequently the crop water requirement in the irrigation areas (Cabral Júnior et al., 2019).

\section{Conclusions}

The Jensen-Haise method overestimated the evapotranspiration values estimated by the standard Penman-Monteith method, whereas the HargreavesSamani, Camargo, Thornthwaite, and PriestleyTaylor methods underestimated the standard equation on the monthly average daily scale.

The HS and JH empirical methods presented the best rates of determination on the daily data scale, with the other methods also showing good correlation and satisfactory statistical indexes, where all obtained performance indexes from "good to very good".

When only the meteorological variables of solar radiation and air temperature are available, the Jensen-Haise, Priestley-Taylor and Camargo methods presented a good correlation with the standard Penman-Monteith method for the estimate of the reference evapotranspiration.

The estimation of reference evapotranspiration by different empirical methods is important in agricultural planning and irrigation management for optimizing water resources of the semiarid regions in São Francisco Mesoregion, mainly due to the spatial and temporal variability of rainfall and drought periods in the Brazilian semiarid regions. Being required according to the data scale range and best local adjustments for precision and accuracy in determining ETo.

\section{Acknowledgments}

This study was financed in part by the Coordenação de Aperfeiçoamento de Pessoal de Nível Superior - Brazil (CAPES) - Finance Code 001. The authors would like to thank the Instituto Nacional de Meteorologia (INMET) by provide the meteorological data.

\section{References}

Allen, R.G., Pereira, L.S., Raes, D., Smith, M., 1998. Crop evapotranspiration: Guidelines for computing crop water requirements. FAO-56, Food and Agriculture Organization of the United Nations, Irrigation and Drainage 300, 1-50. Available: <http://www.scscourt.org/complexcivil/105CV0 49053/volume3/172618e_5xAGWAx 8.pdf >. Access: March 25, 2020.

Althoff, D., Bazame, H.C., Filgueiras, R., Dias, S.H. B., 2018. Heuristic methods applied in reference evapotranspiration modeling. Ciência e Agrotecnologia 42, 314-324. https://doi.org/10.1590/141370542018423006818

Alvares, C.A., Stape, J.L., Sentelhas, P.C., Moraes, G., Leonardo, J., Sparovek, G., 2013. Köppen's climate classification map for Brazil. Meteorologische Zeitschrift 22, 711-728.

Andrade Junior, A.S., Silva, C.O., Sousa, V.F., Ribeiro, V.Q., 2017. Avaliação de métodos para estimativa da evapotranspiração de referência no estado do Piauí. Agrometeoros 25, 181-190. http://dx.doi.org/10.31062/agrom.v25i1.26278

Arraes, F.D.D., Lima Junior, J.C., Oliveira, J.B., Macedo, K.G., Couras, Y. de S., Oliveira, W. C. de, 2016. Parametrização da equação de Hargreaves-Samani para o estado do Pernambuco - Brasil. Revista Brasileira de Agricultura Irrigada 10, 410-419. https://doi.org/10.7127/rbai.v10n100369

Barbosa, H.A., Lakshmi Kumar, T., Paredes, F., Elliott, S., Ayuga, J.G., 2018. Assessment of Caatinga response to drought using MeteosatSEVIRI Normalized Difference Vegetation Index (2008-2016). ISPRS Journal of Photogrammetry and Remote Sensing 148, 235-252. https://doi.org/10.1016/j.isprsjprs.2018.12.014

Silva, J. L. B., Bezerra, A. C., Almeida, C.D.C., Lima, D. F., Andrade, F. H. N., Jiménez, K.J. 
Revista Brasileira de Geografia Física v.14, n.01 (2021) 001-015.

Bier, A.A., Ferraz, S.E.T., 2017. Comparação de Metodologias de Preenchimento de Falhas em Dados Meteorológicos para Estações no Sul do Brasil. Revista Brasileira de Meteorologia 32, 215-226. https://doi.org/10.1590/010277863220008

Cabral Júnior, J.B., Silva, C.M.S., Almeida, H.A., Bezerra, B.G., Spyrides, M.H.C., 2019. Detecting linear trend of reference evapotranspiration in irrigated farming areas in Brazil's semiarid region. Theoretical and Applied Climatology 138, 215-225. https://doi.org/10.1007/s00704-01902816-w

Camargo, A.P., 1971. Balanço hídrico no estado de São Paulo. 3. ed. Campinas: Instituto Agronômico. 24 p. (Boletim técnico 116).

Camargo, A.P., Sentelhas, P.C., 1997. Avaliação do desempenho de diferentes métodos de estimativa da evapotranspiração potencial no Estado de São Paulo, Brasil. Revista Brasileira de agrometeorologia 5, 89-97. Available: <http://www.leb.esalq.usp.br/agmfacil/artigos/art igos_sentelhas_1997/1997_RBAgro_5(1)_89-

97_ETPM\%E9todosSP.pdf $>$.

Carvalho, D.F., Rocha, H.S., Bonomo, R., Souza, A.P., 2015. Estimativa da evapotranspiração de referência a partir de dados meteorológicos limitados. Pesquisa Agropecuária Brasileira 50, 1-11. https://doi.org/10.1590/S0100204X2015000100001

Djaman, K., Balde, A.B., Sow, A., Muller, B., Irmak, S., N'Diaye, M.K., Manneh, B., Moukoumbi, Y.D., Futakuchi, K., Saito, K., 2015. Evaluation of sixteen reference evapotranspiration methods under sahelian conditions in the Senegal River Valley. Journal of Hydrology: Regional Studies 3, 139-159.

https://doi.org/10.1016/j.ejrh.2015.02.002

Djaman, K., O’Neill, M., Owen, C.K., Smeal, D., Koudahe, K., West, M., Allen, S., Lombard, K., Irmak, S., 2018. Crop Evapotranspiration, Irrigation Water Requirement and Water Productivity of Maize from Meteorological Data under Semiarid Climate. Water 10, 1-17. https://doi.org/10.3390/w10040405
Fernandes, A., Mengua, R., Melo, G., Assis, L., 2018. Estimation of reference evapotranspiration for coffee irrigation management in a productive region of Minas Gerais cerrado. Coffee Science 13 , 426-438. http://dx.doi.org/10.25186/cs.v13i4.1463

Figueredo Dantas, G., Oliveira, V.M.R., Dalri, A.B., Palaretti, L.F., Santos, M.G., Faria, R.T., 2016. Desempenho de métodos na estimativa de evapotranspiração de referência para o estado da Paraíba, Brasil. Irriga 21, 481-490. https://doi.org/10.15809/irriga.2016v21n3p481 490

Guimarães Junior, J.A., 2016. Reforma hídrica do Nordeste como alternativa à transposição do rio São Francisco. Cadernos do CEAS: Revista crítica de humanidades 227, 80-88. http://dx.doi.org/10.25247/2447861X.2007.n227.p80\%20-\%2088

Hargreaves, G.H., Samani, Z.A., 1985. Reference crop evapotranspiration from temperature. Applied Engineering Agriculture, 1, 96-99. http://dx.doi.org/10.13031/2013.26773

Ide, A.K., Silva, C.L., 2017. Métodos de estimativa da evapotranspiração de referência na área de influência dos canais da transposição do Rio São Francisco. Revista Engenharia na Agricultura 25, 526-539.

https://doi.org/10.13083/reveng.v25i6.758

INMET - Instituto Nacional de Meteorologia, 2016. Meteorological database for education and research - BDMEP. http://www.bdmpe.inmet.br/

Jensen, M.E., Haise, H.R., 1963. Estimating evapotranspiration from solar radiation. Journal of Irrigation Drainage Division, Proceedings of the American Society of Civil Engineers, ASCE 89, 15-41. Available: < https://eprints.nwisrl.ars.usda.gov/id/eprint/1248 $>$.

Koksal, E.S., Tasan, M., Artik, C., Gowda, P., 2017. Evaluation of financial efficiency of dripirrigation of red pepper based on evapotranspiration calculated using an iterative soil water-budget approach. Science Horticulturae 226, 398-405. https://doi.org/10.1016/j.scienta.2017.08.025

Silva, J. L. B., Bezerra, A. C., Almeida, C.D.C., Lima, D. F., Andrade, F. H. N., Jiménez, K.J. 
Revista Brasileira de Geografia Física v.14, n.01 (2021) 001-015.

Lacerda, Z.C., Turco, J.E.P., 2015. Estimation methods of reference evapotranspiration (ETo) for Uberlândia -MG. Engenharia Agrícola 35, 27$38 . \quad$ https://doi.org/10.1590/1809-4430Eng.Agric.v35n 1p27-38/2015

Li, Z., Chen, Y., Wang, Y., Fang, G., 2016. Dynamic changes in terrestrial net primary production and their effects on evapotranspiration. Hydrology and Earth System Sciences, 20, 2169-2178. https://doi.org/10.5194/hess-20-2169-2016

Liu, S., Su, H., Zhang, R., Tian, J., Chen, S., Wang, W., 2016. Regional Estimation of Remotely Sensed Evapotranspiration Using the Surface Energy Balance-Advection (SEB-A) Method. Remote Sensing 8, 644-658. https://doi.org/10.3390/rs8080644

Lucena, F.A.P., Silva, E.M., Ribeiro, A.A., Simeão, M., Lucena, J.P.A.P., 2016 Revista Brasileira de Agricultura Irrigada 10, 663675, https://doi.org/10.7127/rbai.v10n300404

Marengo, J.A., Torres, R.R., Alves, L.M., 2016. Drought in Northeast Brazil-past, present, and future. Theoretical and Applied Climatology 129, 1189-1200. https://doi.org/10.1007/s00704-0161840-8

Mariano, D.C., Faria, R.T., Freitas, P.S.L., Lena, B. P., Johann, A.L., 2015. Construction and calibration of a bar weighing lysimeter. Acta Scientiarum Agronomy 37, 271-278. https://doi.org/10.4025/actasciagron.v37i3.19368

Muhammad, M.K.I., Nashwan, M.S., Shahid, S., Ismail, T., Song, Y.H., Chung, E., 2019. Evaluation of Empirical Reference Evapotranspiration Models Using Compromise Programming: A Case Study of Peninsular Malaysia. Sustainability 11, 4267 https://doi.org/10.3390/su11164267

Oliveira, A.K.S., Freitas, I.A.S., Silva, T.T.F., Espínola Sobrinho, J., Maniçoba, R.M., Santos, W.O., Bezerra, J.M., Silva, S.T.A., 2020. Reference evapotranspiration during rainy and dry seasons in Mossoró, RN, Brazil. Semina: Ciências Agrárias, Londrina, 41, 109-120. http://dx.doi.org/10.5433/1679-

0359.2020v41n1p109
Pandey, P.K., Dabral, P.P., Pandey, V., 2016. Evaluation of reference evapotranspiration methods for the northeastern region of India, International Soil and Water Conservation Research 4, 52-63, https://doi.org/10.1016/j.iswcr.2016.02.003.

Pereira, A.R., Villa Nova, N.A., Sediyama, R., 1997. Evapo(transpi)ração. Piracicaba-SP: FEALQ. $183 \mathrm{p}$.

Priestley, C.H.B., Taylor, R.J., 1972. On the assessment of surface heat flux and evaporation using large-scale parameters. Monthly Weather Review 100,81-92. https://doi.org/10.1175/15200493(1972)100<0081:OTAOSH>2.3.CO;2

Salama, M.A., Yousef, K.M., Mostafa, A.Z., 2015. Simple equation for estimating actual evapotranspiration using heat units for wheat in arid regions. Journal of Radiation Research and Applied Sciences, 8, 418-427. https://doi.org/10.1016/j.jrras.2015.03.002

Sales, R.A., Oliveira, E.C., Lima, M.J.A., Gelcer, E.M., Santos, R.A., Lima, C.F., 2018. Ajuste dos coeficientes das equações de estimativa da evapotranspiração de referência para São Mateus, ES. Irriga 23, 154-167, http://dx.doi.org/10.15809/irriga.2018v23n1p154 $-167$

Santos, R.D.S., Souza, M.H.C., Bispo, R.C., Ventura, K.M., Bassoi, L.H., 2017. Comparação entre métodos de estimativa da evapotranspiração de referência para o município de Petrolina, PE. Irriga, Edição Especial 1, 31-39. https://doi.org/10.15809/irriga.2017v1n1p31-39

Shiri, J., 2017. Evaluation of FAO56-PM, empirical, semi-empirical and gene expression programming approaches for estimating daily reference evapotranspiration in hyper-arid regions of Iran. Agricultural Water Management, 188 , 101-114. https://doi.org/10.1016/j.agwat.2017.04.009

Thornthwaite, C.W., 1948. An approach toward a rational classification of climate. Geographical Review 38, 55-94. https://doi.org/10.2307/210739 
Varejão-Silva, M.A., 2006. Meteorologia e Climatologia. Ministério da Agricultura e Abastecimento, Instituto Nacional de Meteorologia, 2. ed. (versão digital), Recife-PE. $463 \mathrm{p}$.

Valipour, M., Sefidkouhi, M.A.G., Raeini-Sarjaz, M., 2017. Selecting the best model to estimate potential evapotranspiration with respect to climate change and magnitudes of extreme events. Agricultural Water Management 180, 5060. https://doi.org/10.1016/j.agwat.2016.08.025

Warrick, A.W., Nielsen, D.R., 1980. Spatial variability of soil physical properties in the field.
In: Hillel, D. Applications of soil physics. Cap.2. Academic, New York.

Willmott, C.J., Ckleson, S.G., Davis, R.E., Feddema, J.J., Klink, K.M., Legates, D.R., O’Donnel, J., Rowe, C.M., 1985. Statistics for the evaluation and comparison of models. Journal of Geophysical Research 90, 8895-9055. https://doi.org/10.1029/JC090iC05p08995

Yang Y., Cui, Y., Bai, K., Luo, T., Dai, J., Wang, W., Luo, Y., 2019. Short-term forecasting of daily reference evapotranspiration using the reducedset Penman-Monteith model and public weather forecasts. Agricultural Water Management 211, 70-80.

https://doi.org/10.1016/j.agwat.2018.09.036 